Tér és Társadalom 2. évf. 1988/2.

106

\title{
BESZÁMOLÓ A NEMZETKÖZI FÖLDRAJZI UNIO IPARI VÁLTOZÁSOKKAL FOGLALKOZO BIZOTTSÁGÁNAK 1987. ÉVI KONFERENCIÁJÁRÓL (Rabka, Lengyelország, 1987. szept. 1-7)
}

Az évben Lengyelországban, a Krakkótól 70 km-re fekvó, szanatóriumairól híres Rabka faluban gyült össze az Ipari Változásokkal foglalkozó bizottság. mintegy 13 országból - 30 résztvevővel. A konferencia témájául azoknak a területi hatásoknak bemutatását választották, amelyeket az ipari változások gyakorolnak a munkaeró piacra és a lakosság életkö rülményeire.

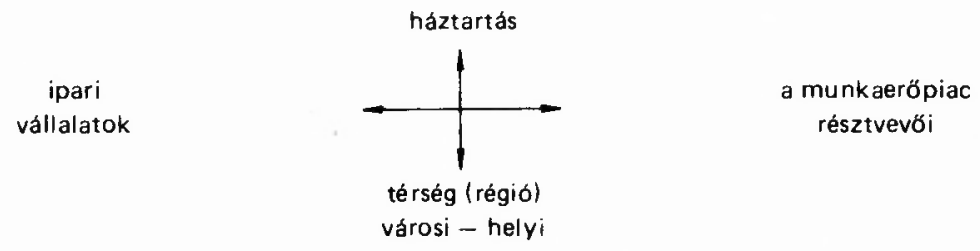

A konferencia tehát tág teret biztositott a legkülönbözóbb témaköröknek: az elóadások között szerepeltek a munkaeró-piaci elméletekkel foglalkozó tanulmányok; az ipari fejlödés vagy visszafejlódés helyi (az egyes országokra jellemzó) kihatásai a lakosság életkörülményeire (lengyel, szovjet, német példák); az iparszervezetnek és szerkezetnek, az ipari termelés, beruházások és a müszaki fejlódés területi kihatásainak bemutatása; az ipari munkások helyzetével (munkakörülmények, bérek, a nói munkaeró helyzete, munkanélküliség stb.) foglalkozó esettanulmányok.

Végül is az elరadások három fó csoportba voltak sorolhatók:

- elméletek

- hat ásvizsgálatok

- összefüggések elemzései.

Ami az elméleti megközelitéseket illeti, nyilvánvalóvá vált, hogy az iparföldrajz elméleti rendszerei, mint a neo-klasszikus, behaviorista, neo-marxista és rendszer-elemzó megközelitései, nem tudják magyarázni, követni a történelmi, gazdasági, területi változások bonyolultságát. Bár a jelenlegi idószak nem alkalmas talán az új elméletek alkotására, nagyon fontos lenne, hogy a meglévó elméleteket kombináljuk egymással, az ipari változásokat vessük össze az elméleti háttérrel, és fogadjuk el az el méletek pluralitását.

A hatásvizsgálatok az ipar tébeli folyamatainak következményeivel foglalkoztak, a környezetszennyezés, a területi ellenör zés, a település rendszer összefüggéseivel, és annak mérhetóségévei, il letve a munkaeró piaci változások hatásával a családok, háztartások életére.

Az összefüggések, tranzakciók elemzései elsósorban az ipari hatásokra adott válaszokat vetették. fel, (akár állami, szervezeti, akár a család, az egyén szintjén).

A következó szeminárium helye Ausztrália lesz a jövó évben, témája az ipar térbeli változásainak :rányítása, kezelése és befolyásolása lesz (Managing of spatial effects of industrial change).

BARTA GYÖRGYI 